\title{
THE END OF CAPITALISM AND THE RETURN OF KOINONÍA
}

Fernando Suárez Müller

University of Humanistic Studies of Utrecht

\begin{abstract}
The financial crisis has not changed the economic structure of capitalism and critics of capitalism have increasingly turned to Marx for solutions. It is argued here that Hegel provides a better theoretical framework than Marx when it comes to understanding current alternatives. Hegel envisioned a society that transcends its capitalistic basis and reactivates communal energies. Thus Hegel can be considered to restore the Platonic ideal of koinonía which refers to the idea of a society organised around the needs of communities rather than individuals. The term has been used in the analysis of early Christianity and has been taken up by the Catholic Church; it is useful now because it has both a deeply metaphysical sense and a political and social reference which gives rise to ideas of right and justice. With this in mind, alternatives to capitalism are discussed which are based on the concept of 'the collaborative commons'. Three recent examples are considered which underpin current activist movements: the peer-to-peer movement of Michel Bauwens, the convivialist movement of Alain Caille and the common-good movement of Christian Felber. For Hegel and for the modern collaborative commons a community-based society marks the end of capitalism.
\end{abstract}

Keywords

Capitalism . Alternative movements . Koinonia . Society in Hegel.

\section{O FIM DO CAPITALISMO E O RETORNO DA KOINONIA}

\begin{abstract}
Resumo
A crise financeira não mudou a estrutura econômica do capitalismo e críticos do capitalismo têm cada vez mais se voltado para Marx buscando soluções. O argumento em destaque propõe que Hegel oferece enquadramento teórico melhor que o de Marx quando se trata de compreender as atuais alternativas. Hegel pressupunha uma sociedade que transcendesse sua base capitalista e reativasse energias em comum. Desse modo, Hegel pode ser considerado o restaurador do ideal platônico de koinonia, que se refere à ideia de uma sociedade organizada tendo em vista as necessidades das comunidades em vez daquelas individuais. $O$ termo foi usado na análise dos primeiros tempos da Cristandade e foi retomado pela Igreja Católica; é útil agora porque apresenta tanto um sentido profundamente metafísico quanto uma referência social e política que traz à tona ideias de direito e de justiça. Com isto em mente, alternativas para o capitalismo são discutidas com base no conceito de 'os comuns colaborativos'. Três exemplos recentes são considerados por apoiar os atuais movimentos de ativistas: o movimento "peer-to-peer" de Michel Bawens, o movimento de convivência de Alain Caillé e o movimento do bem-comum de Christian Felber. Para Hegel e para os comuns colaborativos modernos, uma sociedade baseada em comunidades marca o fim do capitalismo.
\end{abstract}

\section{Palavras-chave}

Capitalismo. Movimentos alternativos. Koinonia. Sociedade em Hegel.

\section{INTRODUCTION}

The financial crisis has not changed the economic structure of our globalized western civilization. Hardly anything has been done about the problem of banks being too big to fail. Basel III is hardly implemented, and even if it were, that would not substantially change the infrastructure of our economy. Bankers are still getting enormous sums of money. The stock 
exchange is functioning as it always did, as if nothing happened. Have we gone back to business as usual? One thing has substantially changed: the shock of the crisis has scarred the minds of many people, although not the minds of economists. The economists looking for alternative economic models are still a marginal minority. But political economy - the idea that economic science very much depends on fundamental political perspectives which are rooted in basic philosophical ideas - has strongly reappeared, and I believe this will change the future of economic science. Economics has gone back to the womb of philosophy, and from there something new will soon enter the world. What has changed fundamentally after the financial crisis is the fact that capitalism, the system legitimating most aspects of our modern economic science (and corresponding academic positions), has decisively lost its comfort zone.

This situation explains why in Europe some bestselling books that are critical about capitalism have appeared with titles that refer to the major work of Karl Marx although they are certainly not proposing anything approaching communism. In 2008 Cardinal Reinhard Marx, playing with his name, entitled his book - that was destined to stay in the bestselling list of the German public journal Der Spiegel for a long time: Das Kapital. Ein Plädoyer für den Menschen (Capital. A Plea for Humanity). More recently (last year) an academic work appeared first in French and then in English: Le Capital au XXI siècle by Thomas Piketty is still on the 'bestseller' shelves of European libraries. Of course these titles have been used for marketing purposes. Cardinal Reinhard Marx does not develop an alternative to traditional capitalism. He advocates the strengthening of the social state based on the value of solidarity; capital, he writes, should become moral (2010, 225). The voluminous work of Thomas Piketty advocates global taxes on capital, because only taxes can equalize the difference between capital incomes and the economic growth rate which, left as it is, will mechanically lead to an increase of severe economic (and therefore social and democratic) inequality (2013, 835). These critical works do not really affect the basics of the capitalist system. Their criticism is nevertheless valuable and valid, and clearly points towards limiting free market ideology, and thus comes close to redefining the idea of economic freedom itself. The fact that these authors use the title of Karl Marx's major work shows that the minds of the reading public have been profoundly changed. Most people in the leading economic nations are becoming aware that an economic system emphasizing individual gain and based on the idea of limitless growth has no future in a world that is fundamentally limited and dependent on ecological stability. 
What also seems clear to these authors who use the title of Marx's major work for marketing purposes is that the Marxist perspective cannot be part of the solution. This is not primarily because soviet communism failed as an economic and political project. It is because Marx's alternative was just to turn capitalism upside down, simplifying the complexity that tradition brings. In this sense Marx was textually a revolutionary thinker. He did not consider the possibility of anything in capitalism being true or valuable. According to Marx capitalism is only there to make communism possible. His dialectical philosophy of history is in fact a linear teleology build on turnovers. If nothing of capitalism is valuable nothing needs to be preserved. Tradition is simplified and is presented as something that must be rolled over. There is no idea of preservation in Marx, no idea of cumulative truth, no sense of tradition, of retaking or recycling old ideas for new purposes. In a progressivist mind like that of Marx there is no place for any type of conservatism. The main cause of this simplifying vision of tradition and society is the base-superstructure axiom of Marx's theory. It is this social materialism that makes it necessary to turn everything upside down. If all products of culture mirror the economic (material) structures dominating society then it is clear that eliminating the base will also ruin the building.

Instead of just turning the building upside down we need to recycle it. A reorganization that destroys truths is condemned to implode. Marx's social materialism amounts firstly to a progressivist view of history, so-called historical materialism, and secondly to a concept of progress by turnovers, so-called dialectical materialism. The new society can only be thought of in terms of discontinuity. Of course the germs of the new must be present in the old. No communism is possible without industrialisation and the appearance of a proletarian class. The conditions making the turnover possible must have come into existence in the old order. However, this does not mean that there is an effort to recycle the old, to emphasize the true structures of the past. This is where the Marxian theory of dialectics differs from Georg Hegel's more sophisticated version. The version of Marxian dialectics is two-dimensional, whereas the Hegelian is three-dimensional. For Marx there is a structure that generates an opposition turning this structure upside down. For Hegel there is a structure that generates an opposition creating a situation in which the truth of both must combine to form something new. Marx thinks in terms of revolution; Hegel in terms of evolution through synthesis.

The purpose of this paper is to show that Hegel offers a better theoretical framework when it comes to understanding current alternatives to capitalism such as "the collaborative commons" characterized by terms like "convivialism", "peer-to-peer society", "common good 
economy", etc.. I would like to show that in his Elements of the Philosophy of Right Hegel envisions the idea of a society that transcends the economic model of capitalism and reactivates communal energies. I believe that Hegel by this restores the old platonic ideal of koinonía. This term denotes a society in which not individuals but communities play a central role. These different, harmoniously linked, communities would blend into the whole of nature. I will first develop some ideas concerning the subject of abandoning social materialism (that can be thought of in either a capitalist way or a communist way) and rediscovering social idealism (which must not be confused with social constructivism). Hegel envisions the end of capitalism and he does so from an idealist perspective. In a second step I will argue that current alternatives to capitalism are, as I see it, part of a general phenomenon that I call the rediscovery of koinonía.

\section{THE RETURN OF IDEALISM}

The Marxian idea of social materialism implies that the means of production dominating culture determine the so-called superstructure of legal and political ideas and intellectual works; "forms of consciousness" (13.8). These ideas and works act as legitimation of existing productive relationships. Social materialism in a liberal sense means that social relations are ultimately based on the idea of material utility. It is in this sense that Adam Smith in his Wealth of Nations declared that the butcher does not act out of benevolence but in regard to his own interest $(1976,19)$. This point is also fundamental in neoliberal discourse where "egoism" in the philosophical sense of "maintaining and enjoying one's own life" constitutes the essence of social materialism (Peikoff 1993, 230). These materialist presuppositions are not totally astray but they are one-sided because there must be something like a spiritual being first that is driven by the idea that its own life is worth living. In this sense Hegel is right that every living being is articulating "ideas" (7.30). According to Hegel the guiding idea - an idea that incorporates many others and makes society possible - is freedom (30). Hegel is not thinking of negative freedom that takes the spiritual being to be free from all kind of external determinations (50). He means a positive freedom, which includes a moment of limitation or restriction, an acknowledgment of dependency. Hegel relates this positive freedom to the dimension of "Sein-Sollen", to "what ought to be" (57). It is therefore a freedom through engagement that we also find in friendships and in love relationships. Hegel (in the preface to Elements of the Philosophy of Right) warns his readers about misinterpreting his idealism in an old-fashioned enlightened way as a social philosophy giving an immediate picture of how things "ought to be" (26). He does not consider his idealism to be an abstract rational construction ("rein vernünftig") but to be a description of 
"what ought to be" based on an analysis of social reality as it developed historically. To Hegel reality is an expression of transcending objective ideas developing through history (42). Positive freedom cannot be considered to be something separate from (social) reality. A person relating everything to herself, interested only in her own subjectivity, can only conceive freedom in terms of negative freedom. When she feels engaged in something specific, then Hegel speaks of a "concept of freedom that is concrete" (57). Positive freedom is not abstract but concrete and related to values expressed in reality. This engagement is what Hegel calls the constitution of the idea of right in reality (61). In German, both being right and being just come together in the word Recht. Of course this does not mean that any arbitrary act of the will is right. If so, there would be no "science of right" (70). The object of engagement must have a rational base. That is why Bildung (the formation of the subject) is so important to Hegel: it enables us to be moral, that is, to engage in right objectives (71). To form oneself means to enrich oneself with insights and knowledge in order to act rightly, which means to act on a rational basis, engaging in right objectives. To know what is right it is necessary to consider the real nature of the things we are dealing with. This comes down to gaining insight into the essence or idea of these things. When Hegel says that the spirit wants to be idea ("Geist will Idee sein") it is precisely this that he has in mind. The person wants to get specific insights into what is objectively just; she wants to make sure that she is engaged in the right thing (79). This longing for what is right is part of the inner world of human beings and in this specific sense the idea of justice is always a part of us, which, of course, does not mean that it is dependent on us. Hegel's vision of the world is dynamic and so is his concept of idealism. The ideal (the dimension of the idea of right) develops through society, both its history and structure. Humanity cannot have the right society all at once. It has to keep searching again and again in order to extend and enact its positive freedom. That is why Hegel's philosophy of right is also necessarily a philosophy of historical and structural stages.

Summarizing, we can say that social materialism in both senses, the liberal and the Marxist, is always one-sided because this type of materialism has to presuppose something underlying the material relations and interests, something existing in a deeper layer which, as the position of Hegel has clearly shown, can be called the realization of the idea of positive freedom. It would therefore be absurd to reduce society and economy to egoistic relationships in a liberal and neoliberal sense or to the basic productive relationships in the Marxian sense. Liberals and Marxists would of course respond: we do acknowledge liberty! But if in their works this is truly the guiding idea of society, as with Hegel, then positive freedom should be the ultimate basis constituting the whole of society. This means that the liberal and Marxist 
versions of social materialism rest upon a deep layered, and unacknowledged, social idealism. Liberalism and Marxism both stem from an implicit social idealism based on the idea of an indefinite search of positive freedom. The historical and structural developments of this search of freedom will take Hegel to delineate an anti- or post-capitalist picture of modern society. This description can shed some light on the historical dimension of the current economic crisis as well as on today's social and intellectual efforts to think beyond capitalism. Let us first have a look at Marx's critique of Hegel's philosophy of right in order to show how Marxism created a shallow vision of society and marginalised the idea of a society of communities that was central to Hegel's social idealism. By this it will become clear why Marxism cannot constitute the philosophical basis of contemporary post-capitalist discourse. A philosophical development of social idealism as it was conceived before Marx seems to be more appropriate to legitimate contemporary post-capitalist discourses.

\section{1 Hegel's Organic and Community-Based State}

What becomes manifest in Marx's critique of Hegel's social philosophy as developed in his part by part comments on the Elements of the Philosophy of Right is that Hegel's idea of the end of capitalism hardly gets any attention. And although Marx does discuss the corporatist alternative proposed by Hegel, he does not seem very eager to understand it as a critique of liberal capitalism. Even the German title of Marx's critique reveals a narrow understanding of the project developed by Hegel (Kritik des Hegelschen Staatsrechts), because it explicitly concentrates on Hegel's philosophy of the state. It suggests that Hegel is just giving an ideological legitimation of the Prussian monarchy and of modern capitalism. It is true that Hegel is trying to give a philosophical legitimation of the political situation of his time. But beyond that Hegel tries to conceive a state model that to a large extent could also function in a republican setting. However, for Hegel a hereditary monarchy seems more plausible because the hereditary element represents the intergenerational part of society which a republican setting is not able to express. In fact Hegel tries to conceive a society in which top-down and bottom-up power relationships form a harmonious unity. He explicitly defends an organic perspective of society as a unity of interdependent and largely autonomous communities. And he compares society with a sphere, as a whole enveloping different communities. Hegel differentiates this organic perspective from the mechanistic perspective of society in which the parts are neither living unities with a certain autonomy nor 
intrinsically interdependent parts, because they do not tend by their own intrinsic nature to interconnect with other unities. This organic view was so common in the romantic period that we can call it the romantic view of society. Moreover Hegel considers constitutional monarchy to be a model capable of building a bridge with tradition. This constitutes the topdown part of Hegel's state theory. It presents a picture of an outer sphere, which is the whole of society revolving around the inner spheres, which are the particular communities existing in society. I think that Marx's critique of the top-down story of Hegel's philosophy of right makes sense, although it is also clear that much of Hegel's philosophical intention escapes Marx. This narrow understanding of Hegel's philosophy of right is due to Marx's base and superstructure theory that apparently is implicitly present in the assertion that Hegel's state theory is nothing but an ideological legitimation of the status quo of capitalist society.

I would like to show that Marx's critique of Hegel's philosophy of right draws a veil over the organic model of society, ignoring the idea of society as a sphere of spheres containing a plurality of communities. Marx's politics therefore necessarily ends up with the idea of a total turnover that sacrifices democracy in the name of a dictatorship of the proletariat. Marx's critique of Hegel's philosophy of right shows that Marxism is intrinsically connected with this idea of a dictatorship of the working class. In this sense the communist alternatives that kidnapped the twentieth century were no accidents at all, but a logical continuation of Marx's intentions. I think that the organic model as well as the idea of a community-based society needs to be rediscovered as an alternative model to both modern economy and current democracy. The modern collaborative commons can find a philosophical grounding in this romantic model that is dismissed by Marxism and that takes society to be an organic unity of collaborative communities having political power and guaranteeing a democratic process that is fundamentally bottom-up. All top-down politics needs a bottom-up legitimation, but the rightness of such a politics depends on the fact of it being "wise", which means that it is in accordance with the essence or nature of the things underlying decision making. A parliamentary system should enable a sphere of rational deliberation and reasoning. Its foremost objective should be to define the nature of things and to determine rightful action and wise advice. To act rightfully or to do justice to something we need to know what defines its nature. Cooperation in the search of "wise action" should therefore be dominant in a parliamentary system. This is how Hegel interprets parliamentarianism. Our current model of party-based parliamentarianism however, emphasizes the rhetorical part of deliberation in which conflict and competition tend to dominate rather than cooperation. A party system that strongly depends on the favour of a 
large electorate and that has to struggle for votes is always likely to underscore the competitive element of the parliamentary system instead of defining a politics focusing on the nature of things. To Hegel parliament is more a place of negotiations than of competition. Not only political parties but different types of communities should be represented. In Politics of Nature (1999) Bruno Latour tries to enlarge the modern parliamentary system in such a way, unknowingly taking up some fundamental thoughts of Hegel who thinks that communities (and not only individuals) should elect their representatives in the legislative chamber. Latour also wants to include ecological communities in the parliamentary system (for instance NGO's representing the voice of endangered wild animals). With such an extension of the concept of parliament it immediately becomes clear why a community-based society in Hegel's sense is needed to rethink politics.

\section{2 From Marx to Hegel}

There are three fundamental elements in Marx's critique of Hegel's philosophy of right that from the start determine the shape of Marxist politics and in a way make it fall short as a serious alternative to capitalism. The most important one is the above-mentioned critique of Hegel's corporatist society. The second one is the critique of Hegel's legitimation of private property. The manuscript of the first part of Marx's Critique of Hegel's Philosophy of Right was lost, as well as a major part of his comments on private property. But in the part that survived there are some passages summarizing Marx's views. A third element concerns the general idealist approach favoured by Hegel. Marx does not articulate a systematic view of social materialism but develops instead a rhetorical critique of idealism that also reveals his antireligious sentiments.

(a) As we have seen, first of all Marx ignores the importance of the diversity of communities existing in society. He also negates the need for their political organization and representation. Instead of acknowledging the complexity and diversity of social spheres Marx creates a flat or uniform society characterized by simplified conflicts. This leads to a notion of "democracy" that completely abstracts from individuals and communities and that anticipates the idea of a dictatorship of the working class. To Hegel both the family, as a basic and natural form of community, and civil society, as the most general economic and political domain, are necessary parts of the modern state. To Marx, on the contrary, these unities are contingent. As we have noted above, Hegel also envisions a parliamentary system based on a corporativist 
system, which means based on economic and social communities that are relatively autonomous. Guilds, cooperatives (Genossenschaften), congregations and diverse forms of communal organization (such as local or regional communities) constitute the basis of larger organizations called the "Estates" (Stände). These provide representatives to the state parliament $(7.456, \S 288-289)$. This view of society presupposes a bottom-up power structure that functions through what can be called cascading democracy. To Marx however this type of cascading community-based democracy is nothing but a bad effort to return to oppressive feudal practices belonging to the Middle Ages. According to Marx, in such a situation each community would be searching to defend its own privileges through endless political discussions. He condemns this political structure by calling it a "democracy of non-freedom" (1.233). A consequence is that Marx ignores the need for autonomous communities, groups or sections within society to be represented in a parliamentary system. This amounts to a political system ignoring social diversity and presupposing the existence of one uniform community that has no need to express disagreements in a parliamentary way. The idea of a dictatorship of the proletariat that finds a first explicit expression in the Communist Manifesto, a text appearing some years later, is in fact nothing but the logical consequence of this negation of the community-based politics proposed by Hegel. To Marx this dictatorship is synonymous with "democracy" in the sense that democracy is the expression of the will of the people.

Marx ignores the fact that for Hegel a community-based society functions as a response to liberal capitalism. For Hegel such a society constitutes a further development in the history of civil society (bürgerliche Gesellschaft) - a development that goes beyond the idea that society is primarily based on a conflict of private interests. This was the main premise characterizing the contract theories of the Enlightenment. The corporative or estate society marks the edge separating the old liberal type of civil society that was based on the idea of egoistic atomism, from a new type of civil society that is focused on cooperation and negotiation (Hegel uses the word Vermittlung). Hegel does not ignore the existence of private interests but according to him there is a higher principle that manages to pacify them. It is not competition but cooperation that seems to dominate Hegel's sphere of corporations (§ 289). In fact Hegel describes the spirit of corporations (Korporationsgeist) as being ultimately concerned with the common good. He uses several terms to express this like "allgemeine Angelegenheit”, “allgemeine Beste”, “öffentliches Wohl” (7.469, § 301). Individuals who feel bound to larger communities experience empirically what the idea of the common good means. They experience a connection to the whole of society through a particular community. 
According to Hegel the communities are therefore a "mediating organ" between the individual and the whole of society (7.471, § 302). Individuals can only experience what it means to be a political being or a citizen by participating in communities. Although corporations also have particular interests, individuals belonging to these communities learn to see things from a perspective of the common good. Both the state and organized communities are motivated by the common good and this would not be the case if we were to take the individual as an atom (7.458). This means that the spirit of corporations according to Hegel always implies an acknowledgement of the rights of existence of different communities ("Berechtigung der besonderen Sphären”, 7.458). And it also implies an openness to what we now would call a "communicative attitude" to negotiation (Vermittlung) which possibly leads to a consensus (a "Möglichkeit der Übereinstimmung", § 304). In summary we can say that the term "Korporationsgeist" used by Hegel seems to accommodate social values such as cooperation, responsibility, negotiation, mediation, recognition, solidarity, etc.. For Marx however talking about the spirit of corporations is an absurdity (he calls the term an "unhappy hybrid", 1.287) because it entangles two things that by definition cannot go together: private interest (the sphere of egoism) and general interest (the common good). Consequently Marx does not acknowledge the need of a reconciliation between the private and the general, which according to Hegel is in fact the only possible way for individuals to experience empirically the idea of the common good. The fact that Marx rejects all need of reconciliation of the private (the individual) and the general (the society) may also have influenced his critique of private property. The private is immediately the social, so that property can immediately be socialized. Since Marx fails to discern the importance of a diversity of communities, he also ends up reducing Hegel's idea to a formal construction. To promote the existence of autonomously organized communities would imply, he says, adding bureaucracy to society. According to Marx Hegel falls back on a new kind of materialism: "Corporations are the materialism of bureaucracy" ("Die Korporationen sind der Materialismus der Bürokratie", 1.247). In fact this type of organization would just multiply the "Staatsformalismus" on different levels of society. Anticipating Max Weber, Marx expresses a profound abhorrence towards the "Spirit of bureaucracy" ("Geist der Bürokratie") that according to him would characterize such a society (1.248). To promote a community-based society would result in a kind of society of "Iron Cages" (to use Weber's expression). The fact that corporations help to reproduce community feelings and values does not impress Marx at all. We may conclude this point by saying that whereas the idea of a community-based society containing a diversity of 
corporations evokes a relatively decentralized society, the Marxian alternative evokes a very centralized structure which is indeed the common structure of all communist countries.

(b) As I mentioned before, Marx's comments on Hegel's theory of property were lost, but in the remaining part of his critique it becomes clear, as I hope to show, that he generally rejects the position that considers private property to be an inalienable right ("unveräußerliches Gut", 1.306). To Hegel private property belongs intimately to the essence of the individual and defines the person per se (“die eigenste Person"). It is essential to self-consciousness and a general expression of a person's free will $(7.141, \S 66)$. To be free, to be in control of one's own destiny, is the most basic form of private property according to Hegel. The possessions that to Hegel are really inalienable are those which determine a person's inner identity like the possession of free will and the possession of moral and religious beliefs (7.141). To Marx these remarks of Hegel constitute not only a legitimation of capitalist relationships; they are also a legitimation of hereditary property (especially of primogeniture, 1.303). Marx therefore rejects the whole idea of the sovereignty of private property ("die souveräne Herrlichkeit des Privateigentums", 1.304). For him, taking private property as something that is inalienable is to transform the person into an entity that is defined by something external, which means that private property becomes an agent determining the person. Property determines man and not man property ("private property has become the subject of the will, the will merely the predicate of property" - "das Privateigentum [ist] zum Subjekt des Willens geworden; der Wille bloß das Prädikat des Eigentums", 1.304). To declare private property to be inalienable comes down to declaring that we are not free because property becomes the real agent. By this the person loses power over her own will. Although Marx starts commenting on the legitimation of hereditary property, he finally rejects the whole idea of inalienable private property (1.306). Whereas in the Communist Manifesto private property is going to be defined in a sociological and economic way as a means of production that ends up with enslaving practices, in his critique of Hegel's philosophy of right, there is a more general philosophical rejection of private property. According to Marx to define private property as an inalienable quality of the person supports and perpetuates social alienation. For Marx, Hegel mystifies private property making a religion out of it (1.306). According to Marx, the old Roman definition of private property was more realistic than any claim of inalienability. In Roman times private property was not seen as a right at all, but as a historical fact based on power and expropriation (1.315). Considering all these things Marx is not bothered by the fact that to denounce power and expropriation we need to relate freedom to the idea of inalienable 
property. For Hegel the possibility of the person losing her freedom in slavery or serfdom is one of the main reasons to say that private property is intimately connected to the person, since a loss of freedom implies that the person is not in possession of her own actions anymore (7.142). It is impossible to think in terms of an alienation of the person without presupposing a basic form of private property. This seems quite compelling. However this is not Hegel's last word on the matter. For Hegel we can only understand the so-called social contract and the existence of economy by the fact that a person can extrapolate herself in possessions that are passed to others. The basics of economics, according to Hegel, consists in donations, exchanges and trade $(7.153,7.166)$. Freeing ourselves from our possessions in order to create a bond with others, is, according to Hegel, a way of externalizing freedom, of bringing freedom into reality $(7.152, \S 71)$. Hegel therefore considers the social contract and economy to be an effort to create a common will that ultimately has the purpose of making possible the "Dasein" (reality) of "Freiheit" (freedom). To Hegel the realization of freedom is explicitly a social (intersubjective) and not only a personal (subjective) task. We may conclude that for Hegel, private property is something that is limited by the idea of the social contract, and this is not based on an entanglement of egoisms but on an intimate will to join with others in pursuit of freedom for all.

(c) A third critical point that influenced later Marxist politics and makes Marxism a less viable alternative to capitalism concerns Marx's rejection of idealism. As I mentioned before, this position is accompanied by a rejection of religiousness and a devaluation of religious communities. Marx rejects what he calls Hegel's pantheistic mysticism. Hegel was not a mystic at all but a rational philosopher defining an idealist position and to classify this position as mysticism is more than rhetoric, it shows a general contempt for religion. It is the expression of a positivist philosophy that wants to be completely neutral to (and even distanced from) religious discourses, contents and feelings. In a pluralistic modern world alternatives to capitalism cannot dismiss the value of religious contents and communities.

\section{3 The Right of Top-Down Structures}

As I have stressed before, Hegel's political thoughts strive to reconcile a bottom-up model of power with a top-down model. The bottom-up story could help to back up contemporary alternatives to liberal capitalism that underscore the social role of communities. I shall show that Hegel envisioned the end of liberal economy. But before doing this I have to 
spend some time on the top-down story which is the better-known part of Hegel's philosophy of right. Marx describes Hegel's apology of monarchy in a way that obscures the distinction Hegel makes between constitutional and absolute monarchy (1.313). Hegel defends constitutional monarchy, not absolutism (7.443, § 278). According to Hegel there must be a position beyond democracy that appoints the magistrates or ministers of the government. A specific person should represent the whole of society including the intergenerational unity of a nation. This focus on the bodily connection between generations is part of his organic comprehension of the state, in which society is a living whole transcending the present situation (7.457, $\S 286$ ). Hereditary monarchy represents the people through time; it represents the unity with past and future generations. What seems important here is the idea of an institutional construct that elevates the concept of people beyond the temporality of decision making. A danger of modern democracies is that politics is very much focused on relatively short time scales ignoring the consequences of decisions for generations far removed from us. Although it makes no sense to stick to the idea of hereditary monarchy Marx is right about that -, it needs to be considered whether the intergenerational element of society deserves a specific institutional representation. The legitimation of democracy today rests only upon the existing generations and their (often improbable) willingness to think about abstract future generations. If we consider Hegel's idea of a community-based society to be reasonable, then it seems imperative to represent in a specific institutional way the part of the nation that belongs to the community of future humanity. Delegates representing this community cannot be elected by it. Democracy is bound to the existing generations, but it should nevertheless be guaranteed that delegates really advocate the interests of future mankind. It would be quite insufficient if a political system could only express the will of the people. It should give some expression to a more universal and less temporal intention. A political system cannot do justice to the nature of things if it is fully based on a bottom-up model. Institutional top-down instruments that are not liable to be changed easily must be built into the state structure. This was in fact the reason Hegel favoured hereditary monarchy, since pure representative democracy (not to mention other forms of democracy) would only emphasize the "momentary". Maybe in a community-based democracy the influence of community representatives should prevail over representatives of individual voters because these delegates also represent the future members of their communities. 


\section{4 The End of Capitalism}

It is astonishing that Marx ignores the fact that Hegel's corporative society is conceived as an alternative to liberal capitalism. The passages in which Hegel expresses his post-capitalistic thoughts are completely ignored. The reaction of Hegel towards capitalism is, as I understand it, more subtle than that of Marx, since he does not reject the market economy as such. Nor does he repudiate private property as such. He rejects the liberal type of market economy already dominant at his time. This is a common trait of many romantic thinkers. Friedrich Hölderlin dedicated much of his fascinating poetic work to picture this opposition. ${ }^{1}$ According to Hegel not only the political system but also the economy should be organized in a community-based way. Hegel cannot be placed in the traditional discourse of national economy based on Adam Smith that starts from egoistic subjects, since for him individuals are guided by the will to build communities and not by egoistic motives. His version of the social contract is based on the will to create a common good society, that is, on the realization of the idea of concrete (positive) freedom. This is totally different from the liberal concept of civil society in which the person as a particular individual is his own specific end $(7.338, \S$ 182). Such an individual does not create a community, but only a temporary association of interests, a "Gemeinsamkeit", and not a "Gemeinschaft", a real unity of mutual concern (7.339). This association is nothing but a system of interconnected interests that only serves to reinforce the selfish aims of the participants ( $\$ 183$ ). According to Hegel this liberal idea of civil society is, however, a necessary phase of history clearing the way for the communitybased corporatist state. This liberal civil society is not based on universal Reason (Vernunft), but on rational convenience (Verstand). It does not pursue the common good (Sittlichkeit), but tends to develop morals from the idea of subjective benefit (Moralität). Hegel acknowledges that liberal society expands industry creating a limitless accumulation of wealth and the maximizing of profits. But it also creates an atomization of society, the reduction and separation of labour that is represented as a solitary action separate from the role of community ( $\$ 243) .^{2}$ For Hegel, this leads to the creation of rabble (Pöbel), to abstract masses where equity, honour and rights are lost ( $\$ 244)$. It necessarily leads to a situation of indignation, rebellion and outrage (Empörung). Hegel in fact describes the creation of the modern proletariat - a description that Marx completely omits from his comments to the

\footnotetext{
${ }^{1}$ See F. Suárez Müller (2004), 624.

2 As Harada has emphasized $(1989,115)$, some of these ideas were already expressed in Hegel's early writings on the Positivity of the Christian Religion (1.134-148).
} 
Elements of the Philosophy of Right. It is very clear that Hegel is not advocating liberal civil society, since he uses unmistakeable disapproving adjectives in his description of the capitalist system. Hegel even expresses deep concerns about the future of a planet in which this system gets globalized. The obsession (Sucht) with gain (Erwerb), he says, will make humanity conquer land and sea endangering the earth's crust (7.391, § 247). Only a community-based economy, in which cooperation and collaboration (Genossenschaft) are the organizing principles, is able to transcend a liberal economy based on selfish individuals $(7.394, \S 251) .{ }^{3}$ The corporative system on the contrary is based on the idea that there is a natural limit (Beschränkung) to our actions - a limit set upon us by natural right based on the essence (or idea) of what things are (§ 254). The end of capitalism envisioned by Hegel is not however the end of the market economy - and this marks an important difference from communism. Nor is there any need to abolish private property. The limits of property should be established by a special institution (called the police) that promotes the common good ( $\S$ 249). ${ }^{4}$ As Tetsushi Harada has shown, Hegel also advocates the creation of the welfare state as being a first step towards a collaborative economy and participatory society (participatory, because corporations to him are like families, "zweite Familien" $§ 252) .^{5}$ Atomistic egoism is institutionally avoided by a community-based organization of society that is not focused on maximizing wealth, but on maximizing the common good and the realization of positive freedom. Michael Thompson is quite right when he argues that the organic model of society that Hegel has in mind is reminiscent of Plato's concept of society as a space in which each individual consciously and actively contributes to the whole $(2013,66)$. I will come back to Plato's idea of an organic community (koinonía) in the next section. Let me finish this section by expressing my suspicion that Marx's equation of Hegel with the liberal theory of selfishness (40.575) and his omission of Hegel's critique of capitalism are perhaps motivated by the desire to ignore a competing alternative model to modern capitalism.

\section{THE RETURN OF KOINONÍA}

If we need a new story to change the world I do not think we should exclude the possibility of recycling philosophical works of the past that are capable of inspiring us. It is because the past is in fact very much present and because I hope that some pasts will be more

\footnotetext{
${ }^{3}$ See V. Hösle (1998), 550.

${ }^{4}$ See Harada (1989), 144.

${ }^{5}$ Harada (1989), 141-146.
} 
present in the future than they are now, that I had to introduce two important stories about the end of capitalism (Hegel and Marx). To understand the appearance of some of today's new discourses of political economy, I think we have to recycle a term that was coined in philosophy long before the existence of modern capitalism. I finished the last section

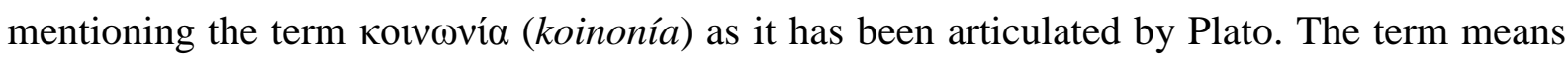
community in the organic sense of a unity of mutually related parts bound together by their affinity. It was in this way that Hegel described the social contract, as an inner longing to be part of a supportive community. I will start this section by a short analysis of the term as it functions in some of the works of Plato, who, to my knowledge, was the first to use the word systematically. I think that the concept of koinonía is a fundamental key to understanding Plato's whole theory of the state (which is beyond the scope of this paper). I think that Hegel's vision of the state is platonic in the specific sense that it implicitly recycles the concept of koinonía. This becomes apparent when Hegel combines the concept of the common good (for which he uses, as I said above, different words like "allgemeine Angelegenheit", “allgemeine Beste", “öffentliches Wohl”, etc.) with the idea of a communitybased society. After a short analysis of the meaning of the word koinonía, I would like to show that some important modern alternatives to liberal capitalism such as the P2P movement, the convivialist movement and the Common Good movement, show interesting similarities with the platonic and Hegelian traditions from which they could benefit when it comes to elaborating a philosophical justification of their positions. I will not engage in a full account of these alternative movements, since I only want to show some general similarities, but I think that a systematic recycling of the intuitions of Plato and Hegel could help explore new models of economics and politics.

\section{1 Christian and Platonic Koinonía}

The concept of koinonía has been extensively analysed in studies on early Christianity and has been taken up in sections of the Catholic Church that try to rethink the idea of ecclesia, the idea of a community of destiny and sharing, based on a deep emotional solidarity among its members. The solidarity is also a deep communion with Christ who is the divine force that makes it possible. As Roberto Esposito has shown, the koinonoi are not just members of the church, they are a brotherhood in Christ $(2009,10)$. According to him the term ecclesia does not cover the concept of koinonía, because this term involves substantial practices of sharing and participation, and is in fact both intimate and ontological. We can 
understand ecclesia to denote a specific community; koinonía, however, refers to a relationship based on sharing our being with others, and this follows from the acknowledgement of being part of a common source which in the Christian context is, of course, Christ. Friedrich Hauck (1957) and Josef Hainz (1981) have emphasized the fact that koinonía refers to a community of sharing based on the acknowledgement of sharing a common essence. The Christian meaning of the term is reminiscent of its platonic origin. The use of the term in the work of Plato is not as well analysed as the Christian variant, but as far as I have been able to research, it is clear that koinonía in Plato has on the one hand a metaphysical and cosmic meaning and on the other hand a social and political significance. The existence of these two dimensions of the concept shows that there is a deep connection between the platonic and the Christian term. An important difference however is that koinonía in the Christian setting - notwithstanding its metaphysical content - remains a human connection (Christ being the human face of God) whereas Plato considers koinonía to be a metaphysical property that not only links together the forms in the world of ideas, but also constitutes the basis of the cosmic order of nature. Koinonía is thereby linked to the idea of right, because the inner possibility of things to relate and share properties determines what the right order of things is. I found the term several times in the context of the concept of

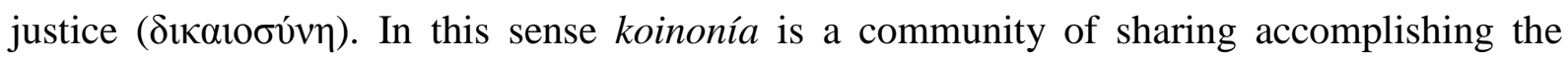
inner necessity of justice. As we have discussed before, according to Hegel, society (the social contract) is based on the idea of the realization of concrete (positive) freedom. His state theory is a philosophy of right, because the realization of positive freedom is in fact the dynamic unfolding of justice. Although Plato does not emphasize this dynamic process, the concept of koinonía plays a role in several levels of being (metaphysical, cosmic, social and political). Both Plato and Hegel have an idealist approach to society, because they link society to an objective idea of justice related to the essence of things and determining the limits and scope of their use. That is why both society and economy in Plato's philosophy must be adapted to the natural order of things. In Plato the specific social meaning of koinonía refers to a community of sharing engaged in an understanding of the essence of things and respecting their natural limitations. A second very important difference with the Christian idea of koinonía is that for Plato the community of sharing is not bound to religion. It is, so to speak, secular, constituting different circles (spheres) in society, and also applicable to the state as a whole. The term also refers to the idea of the common good as the highest goal of the state. 
It is in The Sophist that koinonía appears as the possibility of transcendent ideas combining together and combining with the natural world. In the conversation of Theaietetos with a stranger the human body is said to have an affinity to the empirical world, whereas the mind has an affinity with the real, intellectual world (248b). There is a koinonía between

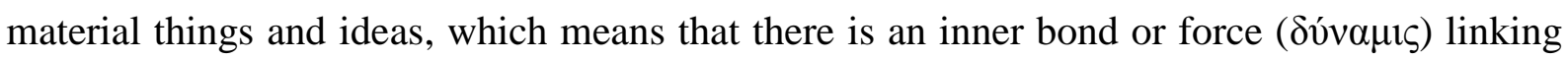
them together by their own nature. This passage demonstrates that koinonía has a metaphysical as well as a cosmic or physical meaning (see for additional passages also 252a, 254b, 256b). In Gorgias the term refers to a metaphysical principle, but here it is already bound to the world of humans: "The wise tell us, o Kallikles, that the heaven and the earth, the gods and man can only exist by community (koinonían) and friendship, as well as through decency, moderation and justice (dikaiótēta)" (508a). This is one of the passages where I found koinonía clearly connected to justice (dikaiosýnē). ${ }^{6}$ Another connection between koinonía and justice can be found in The Republic, where justice is shown to depend on the right order of things (476a). It is in The Laws that the term is used in a strict political sense. A theory of the state should not be about the power of the leaders, but about the right connection between citizens and laws. The state should not be primarily concerned with private individuals, but with the community, with the common good: “(...) the true art of the state [seeks] not the advantage of some individuals, but the common good (korvòv) (...), because the common (kolv) unites, whereas the private tears the states apart (...)" (875a). Plato uses this term explicitly when he comes to reject a theory of society based on selfishness. The whole state theory should be about developing the power of koinonía (875b). Here the term is connected with justice, and the idea of respecting the natural (meritocratic) differences among citizens $(875 b-c)$. Not all people have the same talents and capacities, which means that there is a natural need to subdivide the state in different communities. This was a major issue in The Republic.

Let me end this short analysis of the concept of koinonía with a remark about the main difference between modern and pre-modern thought. In From the Closed World to the Infinite Universe (1957) Alexandre Koyré emphasized the fact that the pre-modern world of Plato was a closed one. As we have seen, Plato takes justice to be part of the world, since there is a natural order in which things and actions have their limits. The platonic world was both a physically and normatively ordered place, and at the same time it was an expression of beauty

\footnotetext{
${ }^{6}$ According to Jean-François Mattéi (1995) platonic koinonía inspired the metaphysics of Martin Heidegger, who tried to elaborate a new worldview for the ecological era. It especially influenced his mysterious idea of Geviert, the Fourfold - a bond between Gods, man, heaven and nature, and these are indeed the terms used by Plato in this passage. The connection between the community of sharing and justice plays, as far as I can see, no major role in Heidegger's metaphysics, but it could be functioning implicitly (in Heidegger's late work the whole sphere of normativity is moved backstage).
} 


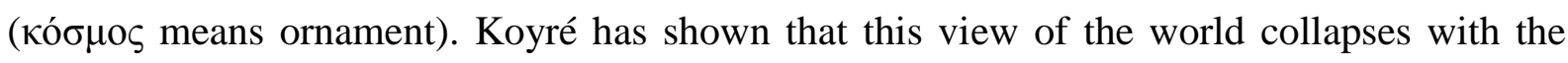
start of modernity. So for modern man the world becomes a limitless domain with no intrinsic normative content delimiting any action. This fuels the fallacy that there are no limits to growth. In order to escape this conclusion we need to reintroduce in some way the idea of a cyclic, closed order that also recuperates something of the inner ability of the platonic cosmos to contain a domain of justice and beauty that can limit the actions of man. In fact this can be summarized by saying that the earth must be thought of as an element of a community-based society.

\section{2 Rethinking the Commons}

The main alternative to modern capitalism today and the first expression of a really new political economy after World War Two can be found in the idea of "the collaborative commons", which has several faces. I want to concentrate on some proposals that are quite recent and constitute a basis for current activist movements. I would like to draw attention to three of them: the peer-movement initiated by Michel Bauwens, the convivialist movement started by Alain Caillé and the common-good movement created by Christian Felber. By giving a general description of their ideas it will become clear that, philosophically, it is possible to align these alternatives with the idealist tradition. Their proclamation of the end of capitalism mirrors the claims made by Hegel some two hundred years ago. They can certainly not be aligned with Marxism.

The peer-to-peer term originates in the context of the new exchange possibilities offered by the internet. It denotes the possibility of sharing digital items even to a point that marks the limits of private property (e.g. copyrights). Hegel showed that intellectual and material property are different things, and that intellectual property fades away in the communications people have with each other (7.104). We could say that digital items are material but that they are dealt with as if they were purely intellectual and volatile. The peerto-peer movement is not a movement that aims to annihilate "intellectual property", but it wants to defend the right of sharing (digital) information. This is the main reason for the popularity of the P2P Foundation, but it hardly gets to the real scope of the idea. To Bauwens, as he sees it in his recent book Saving the World $(2013)^{7}$ and in many blogs, P2P is a philosophy that stretches over politics, economics and religion. It centres on the possibilities

\footnotetext{
${ }^{7}$ The original Dutch title is De wereld redden (2013). The title translation is mine.
} 
created by the internet to build new local and global communities. The philosophy of Bauwens is an integral philosophy based on complexity theory and forms of holism. Bauwens follows to some extent the work of Ken Wilber, but with many reservations, since he considers Wilber to be a neoconservative. ${ }^{8} \mathrm{P} 2 \mathrm{P}$ also adheres to a network approach to reality that we know from complexity philosophies such as Edgar Morin's. This means that reductions and simplifications are to be avoided in order to get an approximating picture of the full web of relationships in which things exist $(2013,155)$. Bauwens is critical of postmodernist approaches which tend to reduce objectivity to subjective interpretations. $\mathrm{He}$ believes in the objectivity of truth and acknowledges that it cannot be reduced to the material world. As it is for Plato the world for Bauwens has a spiritual dimension going vertically from the subatomic world to higher forms of being. There is a deeper dimension of reality responsible for the order of things. In Bauwens' anthropology the spiritual side of man is, from the start, part of a collective (159). ${ }^{9}$ Our economic orientation towards the other cannot be explained using the idea of homo economicus, as this is based on private interests (157). Our longing for the other is a value in itself, and as such is always present in our being. The wrong idea of homo economicus could only originate because people are equipotential. Although we are all equal we have complementary capacities and talents defining who we are. We can only do justice to ourselves and to others if we develop these capabilities and help others develop theirs. The position Bauwens takes presupposes that there is a deeper natural order both of the person and of society (as an association of individuals) to which we should adjust our actions. One aspect of living right is to allow this natural order to realize itself in social circles (communities or associations) based on affinity and complementarity. This very much mirrors the idea of koinonía as described above and it also makes clear why, according to Bauwens, the most basic forms of economics are, as for Hegel, those of giving and sharing. Also the idea that the circles or networks need to be guided by the idea of a common good mirrors the idea of koinonía: "P2P is about organizing our social system in a way in which every individual can freely engage its capacities and talents for the sake of the collective good" (162). Although capitalism to Bauwens was a necessary phase in history that helped to strengthen individualism and freedom, the welfare state was necessary to alleviate social atomism preparing the advent of a community-based society: "The human being wants to be recognised for its participation in social goals of communities, which creates its identity (...). We need a new collectivization (...) based on a free socialization of affinities. This constitutes

\footnotetext{
${ }^{8}$ Bauwens has been inspired by the quadrant of Being used by Wilber, which has important correlations with the idea of the Fourfold of Heidegger and Plato.

9 Bauwens, "The Next Buddha Will Be a Collective" (http://realitysandwich.com/1207/next_buddha_will_be_a_collective/)
} 
the fundament of a new society based on peer-to-peer!" (163). The constitution of these communities is based on free choice. The peer-to-peer movement also envisions an economy based on inner motivation, which means that work must be based on free choice. Compared to the slavery of Antiquity and the serfdom of the Middle Ages, the wage labour system of capitalism is definitely progress, but only one in five people work out of intrinsic motivation. $\mathrm{P} 2 \mathrm{P}$ is about promoting free participation in a labour society (27). This sounds highly utopian but Bauwens considers this development to be a regulating force in an economy already guiding us towards its realization, although there are many things that can still interfere. An economy based on free cooperation within and between communities is the next logical step in the evolution of society (85). This new economic order does not get rid of the market system, but alters its structure from a mainly competitive domain to a dominantly cooperative space (62). Bauwens also acknowledges the basic necessity of hierarchical structures inside organizations, provided that these are based on meritocratic achievements. Only then can these hierarchies be said to be horizontal (49). The whole production system should become a community-based modular system, which means that different labour communities create the pieces which users can assemble in their own way. This stretches the possibilities of a sharing economy (61). I cannot get into specific details such as the introduction of local monetary user-based systems (with temporary validity) or policy measurements restraining the exponential money growth caused by interests. In his political texts Bauwens advocates a strong participatory democracy or polyarchy based on free communities and commoncoalitions $(119,127)$. This very short analysis of the P2P idea suffices to show that this type of commons philosophy starts from the idea of a community-based society that expands over politics, economics and religion (spirituality). It takes society to be an organic space of sharing, constituted by circles that are networked together creating higher circles. This tends towards the idea of a cascading democracy as developed by Hegel.

The Convivialist Manifesto $(2013)^{10}$ of Alain Caillé has been introduced to the public as a collective work. ${ }^{11}$ Among the signatories figure the names of Susan George, philosopher, activist and now honorary president of Attac, and Edgar Morin, the famous philosopher of complexity theory. The term conviviality refers to the work of the Austrian philosopher Ivan Illich, Tools for Conviviality (1973). Illich took the word from Spanish where convivir means living together in close relatedness to each other. The basic idea is to transform modern society, and especially our economy, in such a way that it preserves the market system

\footnotetext{
${ }^{10}$ The original French title is Manifeste Convivialiste (2013). The title translation is mine.

${ }^{11}$ A first identical version appeared under the name of Caillé with a slightly different title (2011).
} 
without conserving liberal capitalism. Although competition (rivalité) is acknowledged as a basic and necessary characteristic of human nature that cannot nor needs to be annihilated, the idea is that society and its different systems (politics, economics, religion, justice, etc.) should be structured by the principle of cooperation (14). The convivialist movement therefore supports initiatives set up by countless communities to actively change the competitive structure on which capitalism is based. The convivialists support the welfare state but want to bring changes in the productive system of our economy stimulating the creation of cooperatives both on the side of production and of consumption (33). Economic relations should be based on mutualism and must be limited by clear ethical standards (13). The cooperatives should integrate de-accelerating ideas of slow food, slow town, slow science, in order to do justice to the natural order of things (including their natural rhythms of being). Society is understood in an organic way as a unity of living parts that depend on each other (the subtitle of the Manifesto reads "Declaration of interdependence”). These communities and cooperatives can stretch from local to global. What the political influence of these associations should be is not specified. The convivialists blame the incapacity of current democracy to cope with the problems of globalization and ecology (19), but the Manifesto does not offer any hints about alternative ways of organizing democracy. Convivialists appreciate that a real global civil society and a world government are things that can only be realized in a far future (35). But convivialists are also cosmopolitans and argue that we should regain power over globalization by creating higher levels of democratic influence strengthening, for example, the European parliament (30). The role religious communities play in their vision of a community-based society is also very important. The formation of religious congregations is encouraged as long as they value universal (pluriversal) humanism (10). Secular congregations and forms of spirituality also need to be encouraged (15). These congregations are indispensable when it comes to addressing the dominant liberal idea that the main purpose of life is to gain financial freedom and reach happiness by making money (21). Every action, every institution, must be considered in the light of four basic questions (moral, political, ecological and economic) which must all interconnect. A religious or spiritual perspective is desired but optional (17). Other important economic changes implied by the idea of a community-based economy are:

- reductions of wealth in the western world to the levels of forty years ago (32/33),

- an urgent transition to renewable energies and to new food practices which are based on the idea of taking and giving back (don et contredon, 33), 
- eradication of business style management in the public sector (21),

- implementation of an ethics of care of nature (souci du soin du monde, 25),

- transformation of the financial world by strong regulation of speculation (34),

- a ceiling on incomes (38), etc., etc..

The idea of convivialité clearly mirrors Plato's koinonía. Society is viewed from a community-based perspective reminiscent of Hegel's bottom-up story, although it is clear that convivialism is much more focused on spiritual (religious) communities. Hegel emphasizes the role of congregations but he is only thinking about Christian communities. And his philosophy of religion does not start from the idea of an equipotentiality of religions. Convivialism on the contrary considers religious pluralism from the starting point of humanistic pluriversalism. Whereas Hegel can be read as offering an interesting idealistic basis to think about the modern collaborative commons, it is clear that the different ways of understanding the commons articulate thoughts that go far beyond Hegel.

The Common Good Movement was created by Christian Felber, a leading thinker of the Attac Movement in Germany and Austria. The work of Felber is very much focused on the systematic development of viable economic alternatives that, put together and developed in the right order, could catapult modernity into a post-capitalistic era. All changes need to be implemented or supported by politics, but the main idea is that the transition to a new market system can only be realized from a bottom-up movement carried out by: on the one hand engaged citizens creating activist communities, so-called "energy fields" (Energiefelder), and stimulating consumer platforms supporting certain types of economy; and on the other hand engaged enterprises and municipalities committing themselves to progressively transforming their own organizations into cooperativist corporations. To this end in Economy for the Common Good (2010) ${ }^{12}$ Felber presents a roadmap, schematically summarized in a matrix containing a relatively large set of values (like transparency, democratic participation, fair trade, ceiling of incomes, corporate social responsibility (CSR) commitments, etc., etc.) which are quantified in such a way as to permit a kind of ethical accountancy (28-34) based on measurements of the common good impact of corporative actions (27). The values and the quantification methods have been developed in collaboration with enterprises that freely work on promoting the ideas of the common good and cooperativism. Through public discussions governments must be inspired to create legislation that protects cooperativist organizations from unfair competition. The focus is on municipal policies which are easier to influence than

\footnotetext{
${ }^{12}$ The original German title is Gemeinwohl-Ökonomie (2010). The title translation is mine.
} 
national or international politics. The set of values proposed by Felber starts with the idea of man's dignity, which is the highest value justifying the social idea of a common good (13). From these first values (dignity and common good) it is possible to deduce all the other values defining a common good society. The competitive nature of the capitalist free market enables the already rich and powerful to exploit their position. It creates a social system of winners and losers. The imbalance of power endangers and undermines democracy (23). According to Felber this has nothing to do with a positive idea of freedom as it is implied in the idea of the common good. The main reason to promote competitiveness is efficiency. Capitalism starts from the axiomatic presupposition that competition is the invisible hand creating the most efficient economic system. General policy should therefore foment competition. But the necessity of a welfare state already marks the limits of such liberal ideology. Today, the idea that competition is the most efficient way of organizing economy is still central, and the current welfare state is construed on the shoulders of a system based on competition. Policy is still followed as if competition is the most efficient way of getting the best quality for the best price. In a cooperative society the dominance of competition would disappear. It would still exist, but it would not be based on capitalist motives. The motivating factor would not be an increase of assets or capital, or the possession of a leading market position. Competition would only be ethically motivated and would feed back into a system based on cooperation and the idea of the common good. Technical and organizational improvements that help reduce prices (or keep them at a certain level) or reach higher quality standards would be shared in order to contribute as soon as possible to the common good. Enterprises that commit themselves to the norms of the common good society therefore take sharing information and knowledge as a central issue. So they naturally make alliances in coalitions of cooperation. Political institutions play an important role in creating a supportive domain for cooperativist corporations. By progressively changing legislation these institutions can on the one hand help by levelling up CSR-standards and on the other hand protect ethically committed companies from unfair competition with companies not engaged in common good standards. Cooperativist alliances can help member companies upgrade their contribution to the common good by creating new compliance standards that must be mutually implemented. This creates a system reinvesting its profits in the common good. The "use of profit" (the legitimate and illegitimate use of it) would become a central factor determining the ethical achievements of a company (36). Felber stresses that cooperativist alliances are not cartels because the main function of cartels is to maximize profit, and this is definitely not the aim of these alliances (45). Cooperating branch associations can also make plans together about 
production levels, ethical prices, reorganizations, fusions, market distribution, etc. (47). This system would also provide society with negative feedbacks on the accumulation of capital by creating income ceilings, limits to company growth, etc. in order to keep or restore the balance inside alliances (62). It is obvious that Felber is trying to promote a community-based society built on the idea of the common good that is central to Plato and mainly focused on a reorientation of the industrial world in the way Hegel anticipated. Hegel conceives corporativist or estate society as a new way of organizing labour. The communities he envisions are mainly labour communities based on the idea of Genossenschaft. Compared to the peer-to-peer movement and convivialism, which respectively underscore internet communities and religious pluralism, it is obvious that there is a stronger affinity between the common good movement and Hegel's corporativism. Like Hegel, Felber presupposes the existence of a hierarchy of values. He takes the principle of human dignity, of the common good and of positive freedom to be the highest values that make other values possible (12-16). Although he says he has collected the values empirically, it is clear that he tries to rationalise them. In any case, the principles and values do not only have an empirical validity but also have a rational validity. Felber presupposes that this rational validity will gain social and political support over time. This is also the main reason he advocates a renewal of democracy based on the combination of representative democracy, direct democracy (as a supplement of representation), and what he calls "participative democracy" (109), which, since it is based on the idea of making democracy possible in corporations mirrors the idea of cascading democracy proposed by Hegel.

\section{FINAL REMARKS}

We have seen that the way Marx imagines the end of capitalism will not help us to understand the current post-capitalist movements known as the collaborative commons. His revolutionary thoughts make him blind to the importance of cultural traditions and the rational elements of a market economy. Marx also ignores the importance of a community-based society. His theory of property disregards the links between individuality and private property. And his whole theory is built on a materialist humanism that makes Marxism fundamentally antireligious. Unlike liberalism that takes the idea of the common good as a promise for the future, Marx's communism is a top-down system that ignores democratic structures. I have tried to show that in order to understand the end of capitalism in a way that makes the role of the collaborative commons clear, it pays to read Hegel's philosophy of 
right. The political economy developed by modern collaborative commons can be understood as a way of upgrading fundamental social, political and economic notions developed by Hegel. Needless to say there are many differences between the idealist tradition and the philosophy of the collaborative commons, but there are many fundamental affinities. The main one being that all these ideas of political economy can be seen to be based on the idea of koinonía, of a community-based society structured by the principle of the common good. I think we can therefore consider the collaborative commons to be a rediscovery of koinonía. Both to Hegel and to the modern collaborative commons the community-based society marks the end of capitalism. This insight can result, I think, in mutual benefits. On the one hand the modern collaborative commons can benefit from the conceptual setting in which idealist philosophy has initially developed the idea of a community-based society. On the other hand current idealist approaches in philosophy could consider the modern collaborative commons to be a new step towards positive freedom, a new expression of the unfolding of historical logic, as anticipated by Hegel.

\section{REFERENCES}

BALZ, Horst; SCHNEIDER, Gerhard (Ed.). Exegetisches wörterbuch zum neuen testament. Kohlhammer: Stuttgart, 1981. v.2.

BAUWENS, Michel. De wereld redden: met peer-to-peer naar een postkapitalistische samenleving. Houtekiet: Antwerpen, 2013. Entrevista a Jean Lievens.

CAILLE, Alain. Pour un manifeste du convivialisme. Bord de l'Eau : Lormont, 2011. 2013.

Manifeste Convivialiste: déclaration d'interdépendance. Bord de l'Eau: Lormont,

ESPOSITO, Roberto. Communitas: the origin and destiny of community. Stanford University Press: $2009\left({ }^{1} 1998\right)$.

FELBER, Christian. Neue Werte für die Wirtschaft. Deuticke: Wien, 2008.

Die Gemeinwohl-Ökonomie. Deuticke: Wien, 2010.

Geld. Deuticke: Wien, 2014.

HAINZ, Josef. “Koinonía”. In: Horst Balz \& Gerhard Schneider, p. 749-755, 1981. 
HARADA, Tetsushi. Politische Ökonomie des Idealismus und der Romantik. Duncker: Berlin, 1989.

HAUCK, Friedrich. Koinonía. In: Gerhard Kittel \& Gerhard Friedrich, p. 804-810, 1957.

HEGEL, Georg Wilhelm Friedrich. Werke. Suhrkamp: Frankfurt am Main, 1986. v.20.

HÖSLE, Vittorio, Hegels System: philosophie der natur und des geistes. Meiner: Hamburg, 1988.

JANICAUD, Dominique; MATTÉI, Jean-François. Heidegger from Metaphysics to Thought. State of New York University Press: Albany, 1995.

KITTEL, Gerhard; FRIEDRICH, Gerhard (Ed.). Theologisches Wörterbuch des Neuen Testaments. Stuttgart: Kohlhammer, 1957.

KOYRÉ, Alexandre. From the Closed World to the Infinite Universe. John Hopkins Press: Baltimore, 1957.

LATOUR, Bruno. Politics of Nature: how to bring the sciences into democracy, Harvard University Press: Cambridge (Mass.), 2004 ( $\left.{ }^{1} 1999\right)$.

MARX, Karl. Marx Engels Werke (MEW). Dietz: Berlin, 1956. v.43.

MARX, Reinhard. Das Kapital: ein plädoyer für den menschen. Knaur: München, 2010 $\left({ }^{1} 2008\right)$.

MATTÉI, Jean-François. The Heideggerian Chiasmus. In: Janicaud \& Mattéi, p. 123-125, 1995.

PLATO. Werke. Wissenschaftliche Buchgesellschaft: Darmstadt, 1990. v.8.

PIKETTY, Thomas. Le Capital au XXI ${ }^{\mathbf{e}}$ siècle, Seuil: Paris, 2013.

ROTMANS, Jan. Introductie. In: Bauwens, p. 11-15, 2013.

SMITH, Adam. An Inquiry into the Nature and Causes of the Wealth of Nations. Oxford: University Press, $1976\left({ }^{1} 1776\right)$.

MÜLLER, Fernando Suárez. Skepsis und Geschichte. Königshausen \& Neumann: Würzburg, 2004.

THOMSON, Michael J. Hegel's Anti-Capitalist State. In: Discusiones Filosóficas, 14/22, p. 44-72, 2013. 